\title{
The Role of Derivation and Compounding in the Process of English Language Acquisition
}

\author{
Nereida Shqerra (PhD Candidate) \\ QSA Qendra Studimeve Albanologjike \\ Lagjja "Kongresi I Elbasanit", Bulevradi "Qemal Stafa", \\ Rruga "Baki Kongoli", Prane ish-dispancerise, Nr: 7242 \\ Email: nereidashqerra@hotmil.com \\ Endri Shqerra MA \\ University of New York, Tirana \\ Email: endrishqerra@hotmail.com
}

Doi:10.5901/jesr.2014.v4n2p117

\begin{abstract}
The communicative approach in this day and age is focused on communication as the most important, and even the single route in learning a foreign language. The advantage of communicative approach is that pupils and students learn the language naturally through practice, nevertheless, this approach neglects derivational as well as word-formation rules which assist pupils to create new words from the existing words they know, thus, to increase their vocabulary, creativity and their independence. Because of the universality of languages, always there are similarities in word-formation rules of the two languages being involved in the process of teaching (L1 \& L2); a fact which enables pupils to transfer derivational awareness of their mother tong (L1) in support of the second language (L2) acquisition. On the other hand, because each language has its own characteristics, there always are differences, which hamper the foreign language acquisition. In such cases, theory and practice should be considered necessary for pupils, and, consequently, additional focus should be given especially to derivational rules. Yet, the difference between derivational and word-formation rules between the two languages being involved should be decisive in determining the amount of time spend on word-formation. In this essay the focus has been given to the similarities and differences between English and Albanian word-formations. As it is demonstrated, there are similarities in derivation and compounding of the two languages. After that, there are and dissimilarities. In the end there is reached the conclusion that Albanian pupils and students would have need of only some more time spend on word-formation, and, in particular on English derivational rules.
\end{abstract}

\begin{abstract}
"Traditional approaches to language teaching tended to place morphological issues (word-formation) at the forefront. In recent times, however, with the arrival of the communicative trends, the learning and teaching of languages no longer focuses on the description of the language itself and, as a corollary, on morphological issues, but on language as a means of communication. As a result, the emphasis is no longer given to morphological issues (word-formation), but to meaning and use of words in communicative situations. In our opinion, this has led to an undesirable disregard for the internal structure, the form, and the correct or accurate production and productive creation of words." [Balteiro, I. 2011, 26]
\end{abstract}

Derivation and Compounding are important components in the process of second language learning; even "wordformation mechanisms and rules appear at least as important and necessary for non-native speakers as for native speakers" [2011, 26]. Through them we create new words, thus, this way we enlarge our vocabulary by creating new words which derive from the existing words we know. Balteiro, I. [2011, 28] demonstrates in his work "that a typical educated speaker of Turkish, with a lexicon of approximately 20,000 noun roots and 10,000 verb roots, could dispose of more than 200 billion words based on this lexicon", thus, word-formation rules "allow the learner's independence and autonomy" [2011, 28].

In this essay I shall demonstrate the necessity of incorporating word-formation's rules in the grammar books used in high schools and Universities. Pupils need to learn the word-formation rules which have the same importance with exercises about derivation. The principal argument in this essay - based on the similarities and differences between Albanian and English word-formation - is that Albanian pupils and Students would require only some more time spend on morpheme's combination rules of English word-formation, mostly on affixes. 
In English there are derivation rules which determine the change of the grammatical category of the word in the process of affixation. These rules are summed up below, however, in derivational exercises we may add simpler rules like: suffix (-ize) combines with nouns (hospital) to give verb (hospitalize). The information for the combinations that each morpheme, essential to be given in the requirement of the exercise, enters helps pupils in solving the exercise as well as in learning and memorizing these rules. Though exercises in grammar books may require simpler rules, below we have presented the derivational rules which explain even the multiple level of word structure as well as determine the correct affixation in complex structures.

1. Verb plus suffix gives noun

2. Adjective plus suffix gives noun

3. Noun plus suffix gives verb

4. Noun plus suffix gives adjective

5. Prefix plus adjective gives adjective

In the case of the word (organizational) we have multiple levels of the word structure. Although complex, this word has a structure according to the derivational rules.

1) The third rule allows the verb (organize) to consist of a noun (organ) and an suffix (-ize)

2) The first rule allows the noun (organization) to consist of a verb (organize) and an suffix (attion).

3) The fourth rule given above allows adjective (organizational) to consist of a noun (organization) and a suffix (al).

In some other cases the internal structure of a complex word is not obvious. The word (unhappiness) may be analyzed as:

1) Adjective (happy) plus suffix (-ness) to give noun (happiness)

2) Prefix (-un) plus noun (happiness) to give noun (unhappiness)

By considering the properties of the prefix (un-) we can say that (un-) combines quite freely with adjective (happy), than the adjective (unhappy) combines with the suffix (-ness) to give noun (unhappiness). The steps in process of affixation for (unhappiness) are as follows:

1) Prefix (un-) plus adjective (happy) to give adjective (unhappy)

2) Adjective (unhappy) plus suffix (-ness) to give noun (unhappiness) [Shqerra, E. 15, 2009].

Hence, in order to ensure that the proper suffix appears in each structure, pupils and students who study English as a second language have to consult these derivational rules of English language.

Our focus in this essay, in addition to the derivational rules, is on the comparison of the word-formation of Albanian and English languages for the reason that, as Keifer, M. J, \& Lesaux, N. K. [2008, 3] argue, "the students first language (L1) proficiency influenced the transfer of the morphological awareness in support of the second language acquisition. White (2000) and Grass \& Selinker (1983/1992) brought forth arguments that... the acquisition process constructs an implicit mental representation of language so that they are able to make contrasts between L1 and L2". Keifer, M. J, \& Lesaux, N. K. [2008, 3] argue that pupils and students can transfer their morphological knowledge of their first language (L1) to the second language (L2) because of the similarities that languages have with each other, thus, making easier the process of the second language acquisition. Keifer, M. J, \& Lesaux, N. K. [2008] studied Spanish-speaking English language learners. Our study is focused on Albanian-speaking English learners, so, our concern is over the similarities as well as over the contrast of the two languages.

First, there are lexicon similarities in the process of affixation in the two languages. We can mention the derived word (erresire, darkness). In Albanian language suffix (-sire) combines with adjectives (i erret) to give nouns (erresire). In English also, the corresponding suffix (-ness) combines with adjectives (dark, happy) to give nouns (darkness, happiness). There are similarities even in the compound words of these two languages. Among the many similarities we can mention verbal compounds. In Albanian we have adverb (mire) plus verb (pres) to form a verbal compound (mirepres). The same process is in English: adverb (well) plus verb (come) gives verbal compound (welcome) [Shqerra, $\mathrm{E}, 60,2009]$.

Prefixes in both languages usually do not change the grammatical category of the word with which they combine. In English language prefix (un-) combines with adjectives and participles to give adjectives and participles: (unfair, unassuming, unexpected). Prefix (mis-) combines with verbs, abstract nouns, participles without changing the grammatical category of the word: (misinform, misconduct, misleading). Prefix (-mal) combines with verbs, abstract nouns, participles, adjectives to give verbs, abstract nouns, participles and adjectives: (maltreat, malfunction, malformed). In Albanian language prefix (per-) combines with verbs, nouns, adjectives and adverbs to give verbs, nouns, adjectives and adverbs: (perforcoj, permase, i perflakte). Prefix (pa-) combines with nouns to give nous (pakenaqesi). 
Suffixes in both languages as a rule change the grammatical category of the existing word. In Albanian, noun plus suffix (-ar) gives noun (vreshtar). Verb plus suffix (-s) gives noun (blere- bleres). Adjective plus suffix (-sire) gives noun (erresire). In English we have adjective forming suffixes (-ful, -less, -ly, -like, -y, -ish, -ian) which combine with nouns to give adjectives (useful, childless, cowardly, childlike, hairy, foolish, Darwinian). Here we can mention verb forming suffixes and adverb forming suffixes which change the grammatical category of the existing word [5-20, 2009].

Conversion, very common in English, is similar with words formed without affixes of Albanian language. Through conversion a new word is created without altering the shape of the existing word by the process of affixation in both languages. In English we have (butter, water) as nouns and (butter, water) as derived verbs. Even though it is a characteristic of English, we do have words formed without affixes in Albanian language. The verbs (qull, krimb, kyc, ndrysh) are created from corresponded nouns of Albanian language as [qull(i), krimb(i), ndryshk(u)]. Therefore, conversion is almost the same in both languages; it changes the grammatical category of the existing word (from noun to verb) in both these two languages. The difference between the conversions of the two languages is mostly phonetically. In English language there is a shift in stress in cases when we have a noun derived from a verb. The stress shifts from the last or the second syllable at the verbs to the first syllable in the derived nouns [5-22, 2009].

We can maintain that the similarities between word-formation's rules of the two languages "influence the transfer of derivational awareness in support of the second language acquisition" [Keifer, M. J, \& Lesaux, N. K. 2008, 3]; therefore, the part of the theory similar in the two languages, instructed step by step to pupils and students of a second language, facilitates the second language learning because they use their proficiency in their first language in support of the second language acquisition. As Balteiro, I. [2011, 31] upholds "learners acquire and learn more easily (1) those lexical items whose prefixes are either identical or at least similar to those in the mother tongue".

On the other hand, there are and differences between word-formation of the two languages which evoke difficulties for pupils; thus, make the second language acquisition a difficult task. In this part of the essay we shall present the differences between the word-formation of the two languages. It has been concluded that the dissimilarities generally are due to the characteristics of Albanian word-formation which do not exist in English word-formation.

There are lexicon differences between the two languages: in English we have preposition (after) plus noun (thought) resulting in (afterthought). Its equivalent in Albania (mendim i mevonshem) is not a compound noun. In English we have adjective (good) plus -ing participle (looking) resulting in (good-looking). Its equivalente in Albanian ( i pashem) is not a compound word $[50-65,2009]$.

There are many characteristics of Albanian word-formation which do not exist in English word-formation. In Albanian language, some words, though they seem as if are created by prefixes, are created by adding the former article (nyje e perparme) (i) to the participles of the corresponding verbs and are thus a characteristic of Albanian language. So, the adjective (i perdredhur) is created by adding the former article (i) to the participle (perdredhur). The use of the former article is more evident to the adjectives (i perbuzur, i pergjakur, i perkrahur) which are created by adding the former article (i) to the participles of the verbs (perbuzur, pergjakur, perkrahur). Another characteristic of Albanian language, which does not exist in English word-formation, are words formed by adding a prefix and suffix simultaneously. In such cases, the prefix and suffix must stay in order for the word to attain its meaning: pergjithesoj, perfundoj, zbukuroj, pergenjeshtroj. In such cases we cannot remuve the prefix or the suffix. (Pergjith) cannot stand as a word in Albanian, nor can (gjithesoj) [5-40, 2009].

In the compounds of English language, the first element modifies the second and it is the second element which defines the word's meaning; thus an (apple-tree) is a tree and a (tree-fruit) is a fruit. In most of Albanian compounds the first element modifies the second as in (kryeqytet, qytet i kreut) which is a city (qytet). In other cases the second element modifies the first as in (kokeshkemb) where (shkemb) modifies the noun (koke) and the compound's meaning is determined by the first element (koke) [5-40, 2009].

Another characteristic of Albanian language are the attached words (fjalet e pernhijtura). They have an imperative meaning as in (kushtrim). Attached words are created historically by the people as (kushtrim) which is created by (kush eshte trim). An additional characteristic of attached words (fjalet e perngjitura) is that they cannot be divided in two words like other compound words, so (dosido) cannot be divided into (do si do).

Blends, Clipping and Backformation are mostly traditional in English language; however, there are cases of them in Albanian language. Blends are words created from parts of two existing words as (motel) which is created by (motor hotel). Clipping is the process whereby a new word is created by shortening a polysyllabic word. The shortening may occur at the beginning of the word as in (phone) created by (telephone), at the end of the word as in (photo) created by (photograph) and at both sides of the word as in (flu) created by (influence). In Backformation, a new word is created by shortening the existing word. Cases of Backformation include (donate) created by (donation) [5-40, 2009]. 
The dissimilarities between the two word-formations more often than not belong to Albanian word-formation, making thus easier for Albanian pupils to learn English word-formation. Albanian word-formation has its own characteristics, as the former article (nyja e perparme), and attached word (fjalet e perngjitura), which are not part of English word-formation. Words formed by adding a prefix and suffix simultaneously is another characteristic of Albanian language which is not part of English word-formation. In English compound words the first element modifies the second. In Albanian the first element modifies the second, but there are cases when the second element modifies the first. On the other hand, the characteristics of English word-formation, like Bleds, Cliping and Backformation, even if infrequently, belong to Albanian word-formation. For this reason, Albanian pupils and students do not encounter many difficulties in learning English word-formation. The major difficulties are in the process of affixation and root combination, with the earlier being the most onerous.

Balteiro, I. [2011, 32], who seems to be the proponent of traditional approaches, reaches the same conclusions over the importance of the word-formation rules, but, in a way, the role of the theory (word-formation rules) seems to be overemphasized. Even though he mentions that learners creative power - improved by the knowing the word-formation rules - may produce words not completely accurate in all occasions, his conclusions do not mention the importance of derivational exercises used by communicative approach.

"We may conclude that (1) conscious and appropriate teaching of word-formation rules and their particular mechanisms help learners to be autonomous and produce accurate formations or lexical items, as the prefixes in the corpus have proved. (2) The learners' native language plays an important role in the study of L2 morphology, as it is often used as a starting point to form similar derived units in the L2. (3) Concentration on those morphological and semantic differences between L1 and L2 prefixes contributes to effective learning and, consequently, to increase the learners' lexical production. In spite of this, it cannot be disregarded that, once taught (4) learners may use their creative power to form words they have probably never encountered before (i.e. non-entrance, non-human, non-married) but these may not necessarily and in all occasions be completely accurate...we believe that the similarities and dissimilarities among English affixes (in this case, prefixes), as well as those dissimilarities between English and Spanish prefixes, should determine the amount of time to be spent on this area and on each prefix" [Balteiro, I. 2011, 32].

My argument, however, is in accordance with Traugott's conclusion; theory coupled with practice. As Traugott, E. [1980] argues, "Derivational morphemes, as we have seen, are unpredictably restricted in their combination, and unpredictable in their effects on meaning. Hence, not only do speakers have to learn the meaning of all morphemes individually, they also have to learn what combinations each morpheme enters and what each of these combinations means. The grammar has to capture these idiosyncratic facts". The role of word-formation rules to this end is indispensible, but, as indicated earlier from the lexicon differences of the two languages, we may conclude that morphemes are unpredictable in their combinations; hence practice is indispensible, but, coupled with word-formation rules.

Finally, as Balteiro's, I. [2011, 32] concludes, "the similarities and dissimilarities among English affixes (in this case, prefixes)" along with the dissimilarities between English and Albanian prefixes (word-formation) ought to be an important factor in deciding about the time required to be spend on word-formation.

To conclude about the time needed to be spent on word-formation's rules we have to be based on the similarities and differences of the word-formations of the two languages. As it was concluded earlier, the dissimilarities between the two word-formations more often than not belong to Albanian word-formation, making thus easier for Albanian pupils to learn English word-formation. The focus has to be given mainly on affixes. Here should be said that English language has more affixes than Albanian language. This fact would call for more efforts from Albanian pupils and Students to get used with them. What's more, even though there are similarities between English and Albanian affixes, English has different rules in their combinations compared to Albanian language. Hence, Albanian pupils would require only some more time spend on morpheme's combination rules of word-formation, mostly on prefixes.

\section{References}

Balteiro, I. $(2011,1)$ Awareness of L1 and L2 Word-formation Mechanisms for the Development Of a More Autonomous L2 Learner. An International and interuniversity Journal of Foreign Lnaguage Didactics. Retrieved on March 13, 2014 from: http://www.ugr.es/ portalin/articulos/PL_numero15/2.\%20ISABEL\%20BALTEIRO.pdf

Celiku, Met and Mustafa Karapinjalli (1998). "Gramatika praktike e gjuhes shqipe". Tirane. "Toena"

Kieffer, M. J., \& Lesaux, N. K. (2008). The role of derivational morphological awareness in the reading comprehension of Spanishspeaking English language learners.

Reading and Writing: An Interdisciplinary Journal, 21, 783-804. Retrieved on March, 12, 2014, from: http://www.academia.edu/336542 
/Review_Article_The_Role_of_Derivational_Morphological_Awareness_in_the_Reading_Comprehension_of_Spanishspeaking_English_Language_Learners

Lloshi, Xhevat and Kristaq Cipo (1972). "Studime mbi leksikun dhe formimin e fjaleve ne gjuhen Shqipe". Volumi 1. Tirane. "Mihal Druri". Qesku, Pavli (2000). "Fjalor Anglisht- Shqip". Tirane. "Botimet EDFA"

Shqerra, Endri (2009). "C.A. of word-formaion in English and Albanian languages". Tirane "Ngjyrat e Kohes" Tafani, Vilma (2002) ."Analize Teksti dhe tekstlinguistik". Cikel leksionesh. Universiteti: "A. Xhuvani".

Traugott, Elizabeth (1980). "Linguistic for students of literature". USA. "Standford University" 